\title{
Screening of alginate lyase-excreting microorganisms from the surface of brown algae
}

Mingpeng Wang ${ }^{1}$, Lei Chen ${ }^{2}$, Zhaojie Zhang ${ }^{3}$, Xuejiang Wang ${ }^{4}$, Song Qin ${ }^{2 *}$ and Peisheng Yan ${ }^{1,5^{*}}$

\begin{abstract}
Alginate lyase is a biocatalyst that degrades alginate to produce oligosaccharides, which have many bioactive functions and could be used as renewable biofuels. Here we report a simple and sensitive plate assay for screening alginate lyase-excreting microorganisms from brown algae. Brown algae Laminaria japonica, Sargassum horneri and Sargassum siliquatrum were cultured in sterile water. Bacteria growing on the surface of seaweeds were identified and their capacity of excreting alginate lyase was analyzed. A total of 196 strains were recovered from the three different algae samples and 12 different bacterial strains were identified capable of excreting alginate lyases. Sequence analysis of the 16S rRNA gene revealed that these alginate lyase-excreting strains belong to eight genera: Paenibacillus (4/12), Bacillus (2/12), Leclercia (1/12), Isoptericola (1/12), Planomicrobium (1/12), Pseudomonas (1/12), Lysinibacillus (1/12) and Sphingomonas (1/12). Further analysis showed that the $L J-3$ strain (Bacillus halosaccharovorans) had the highest enzyme activity. To our best knowledge, this is the first report regarding alginate lyase-excreting strains in Paenibacillus, Planomicrobium and Leclercia. We believe that our method used in this study is relatively easy and reliable for large-scale screening of alginate lyase-excreting microorganisms.
\end{abstract}

Keywords: Alginate lyase, Gram's iodine, Alginate degradation, Screening, Brown algae

\section{Introduction}

Alginate is an acidic linear polysaccharide found widely in cell walls of brown algae. It has been widely applied in food, cosmetic and pharmaceutical industries due to its unique physical properties to form gels (Wong et al. 2000). Alginate is composed of $\alpha$-L-guluronic acid (G) and $\beta$-D-mannuronic acid (M) as structural units. Two kinds of hexuronic acid residues were linked by 1,4-O-glycoside bonds and can be degraded into alginate oligosaccharides (AOs) with low degree of polymerization by alginate lyases (Gacesa 1988; Ji 1997; Preiss and Ashwell 1962). As enzymatic degradation products of alginate, AOs are small and unsaturated alginate fragments with double bonds at the non-reducing end (Preiss

\footnotetext{
*Correspondence: sqin@yic.ac.cn; yps6@163.com

1 School of Municipal and Environmental Engineering, Harbin Institute of Technology, Harbin 150090, China

${ }^{2}$ Yantai Institute of Costal Zone Research Chinese Academy of Sciences,

17 Chunhui Road, Yantai 264003, Shandong province, China

Full list of author information is available at the end of the article
}

and Ashwell 1962; Zhu and Yin 2015). These fragments with different structure and size exhibit various biological activities such as promotion of plant growth, anti-microbial, anti-oxidant, anti-tumor and immunomodulation (Falkeborg et al. 2014; Khan et al. 2012; Park et al. 2016; Saigusa et al. 2015; Wan et al. 1992; Xu et al. 2015; Yang et al. 2015; Zhou et al. 2015).

Alginate lyases are important and indispensable tools for production of AOs with special bioactivities (Wong et al. 2000; Zhu and Yin 2015). However, there are almost no commercialized alginate lyases with low cost and high yield until now. The narrow substrate specificity and low enzyme activity of existing enzymes still limit the industrial production of alginate oligosaccharides (Dou et al. 2013). Therefore, it is essential to continuously search and identify novel alginate lyases with high enzyme activity and wide substrate specificity from different sources. Nowadays, hundreds of alginate lyases have been isolated and identified from algae, marine mollusks and many kinds of microorganisms (Kawamoto et al. 2006; 
Matsubara et al. 2000; Zhu et al. 2015b, 2016a, b). Especially, different microorganisms have been reported to degrade alginate and become the most important sources of alginate lyases.

In order to acquire more alginate lyase-excreting microbes, a simple and efficient screening method needs to be developed. As an easy and convenient testing method, plate assay associated with constrain condition is traditionally used for bacteria screening. A number of alginate degrading strains were isolated by plate assay using different reagents as enzyme-producing indicator (e.g., cetyl pyridinium chloride, ruthenium red, calcium chloride, ethanol) (Gacesa and Wusteman 1990; Baron et al. 1994; Takeshita et al. 1991; Huang et al. 2013). Generally, a clear zone would occur around the alginate lyase-excreting colony after using the chromogenic agents. These qualitative methods make it possible to visualize the enzyme activity and can be applied to detect alginate lyase produced by bacterial colonies. However, the indistinct border and long reaction time of existing methods make the judgment of clear zones fairly difficult and inconvenient. The existing methods are still low efficient for revealing alginate lyase-excreting microbes at large scale. Recently, Sawant et al. (2015) reported that Gram's iodine was an excellent chromogenic agent for revealing alginate lyaseproducing colonies on agar plates. According Sawant's result, Gram's iodine could form distinct clear zones around the alginate degrading microbial colonies within 2-3 min. It was more effective than other chromogenic agents.

In this paper, we applied Gram's iodine as chromogenic agent and a modified plate method with oxford cup to screening and compare alginate lyase-excreting microorganisms that are associated with the brown algae. Our goal is to screen novel alginate lyases at large-scales.

\section{Materials and methods}

Algae collection and bacteria isolation

Three kinds of brown algae Laminaria japonica ( $L$. japonica), Sargassum horneri (S. horneri) and Sargassum siliquatrum ( $S$. siliquatrum) were collected from the coast of Nanhuangcheng Island, China $\left(38^{\circ} 21^{\prime} \mathrm{N}\right.$; $120^{\circ} 54^{\prime} \mathrm{E}$ ), transferred to our laboratory and kept at $4{ }^{\circ} \mathrm{C}$ in a refrigerator. Each seaweed sample was cut into small pieces $(2 \mathrm{~cm} \times 2 \mathrm{~cm})$. Ten grams of every sample were placed in a petri dish with $10 \mathrm{ml}$ sterile water. The petri dishes were incubated at $30{ }^{\circ} \mathrm{C}$ until bacteria growing on the surface of seaweeds were easily observed with naked eyes (2-5 weeks). The bacteria were collected and diluted with sterile water. Aliquots $(100 \mu \mathrm{l})$ of diluted sample were spread on screening plates consisted of $0.5 \%$ sodium alginate, $0.5 \%$ ammonium sulfate, $0.2 \%$ dipotassium phosphate, $0.1 \%$ magnesium sulfate, and $2 \%$ agar (ALG plates) (pH 7.2-7.4). The plates were incubated at $30{ }^{\circ} \mathrm{C}$ and checked daily until colonies were visible with naked eyes. Morphologically different colonies were numbered and transferred onto a new plate with the same medium. The new plate was incubated at $30{ }^{\circ} \mathrm{C}$ to form visible colonies, while the original plates were stained with Gram's iodine solution (Sigma, St. Louis, USA, catalogue HT902). The clear zone around the strain colony indicated that the strain secreted alginate lyase into the medium (Sawant et al. 2015). The number of strains with clear zone was recorded and these strains were selected for further analysis.

\section{Amplification, sequencing and phylogenetic analysis of the $16 \mathrm{~S}$ rDNA}

The genomic DNA of each strain was extracted by the EasyPure genomic DNA kit (Transgen Biotech, Beijing, China, catalogue \#EE101-01). The 16S rRNA gene was amplified by PCR using primers 27F (5'-AGAGTTTGATCCTGGCTCAG-3') and 1492R (5'-TACGGTTACCTTGTTACGACTT-3'). The enzyme was EasyPfu DNA polymerase (Transgen Biotech, Beijing, China, catalogue \#AP211-01). The amplified DNA fragments were sequenced by Sangon Biotech Inc. (Shanghai, China). The sequencing data were analyzed using Basic Local Alignment Search Tool (BLAST 2.3.0) (https://blast.ncbi.nlm. nih.gov/Blast.cgi) and bacterial species were identified based on sequence identity from the database. Phylogenetic trees were constructed using neighbor-joining method and Kimura two parameter model in MEGA 5.1 program (Kumar et al. 2008).

\section{Gram staining and microscopic observation}

Fresh cells grown on ALG plate were picked up and spread on a microscope slide and stained with crystal violet (Beveridge 2001). The cells were observed with an optical microscope (Olympus BX51) using a 100× objective. Images were taken using an Olympus DP72 camera.

\section{Alginate lyase activity assay}

The identified strains were inoculated into $100 \mathrm{ml}$ of liquid ALG medium ( $\mathrm{pH} 7.0$ ) and incubated at $30{ }^{\circ} \mathrm{C}$ for $24 \mathrm{~h}$ with constant agitation $(200 \mathrm{rpm})$. The culture was centrifuged at 12,000 $\mathrm{rpm}$ for $5 \mathrm{~min}$ and the supernatant were collected. Protein concentrations of the supernatants were detected using a protein quantitative kit (TransGen Biotech, Beijing, China).The enzyme activity was measured by two different methods:

\section{Gram's iodine method}

$200 \mu \mathrm{l}$ of supernatant were added into an oxford cup and was placed on the surface of the ALG plate. The plates 
were incubated at $30{ }^{\circ} \mathrm{C}$ for $24 \mathrm{~h}$ and then stained with Gram's iodine solution. The inner and outer diameters of the cleared zone were measured and the total area of the cleared zone was calculated. One unit of enzyme activity was defined as the amount of enzyme required to increase the cleared zone area by $0.1 \mathrm{~mm}^{2} / \mathrm{min}$.

\section{Ultraviolet absorption method}

$200 \mu \mathrm{l}$ of supernatant were mixed with $1.8 \mathrm{ml}$ liquid ALG medium. The mixtures were incubated at $30^{\circ} \mathrm{C}$ for $24 \mathrm{~h}$. The mixtures were heated to $100{ }^{\circ} \mathrm{C}$ for $10 \mathrm{~min}$ to stop the reaction. Absorbance at $235 \mathrm{~nm}$ was measured to determine the enzyme activity. One unit of enzyme activity was defined as the amount of enzyme required to increase 0.1 of the absorbance value at $235 \mathrm{~nm} / \mathrm{min}$ (Preiss and Ashwell 1962).

\section{Determination of optimum conditions for producing alginate lyase}

Effects of temperature, $\mathrm{pH}$ and alginate concentration on alginate lyase activity were tested using the selected enzyme-excreting strains. The strain incubated in $100 \mathrm{ml}$ of ALG medium at $30{ }^{\circ} \mathrm{C}, 200 \mathrm{rpm}$ for $24 \mathrm{~h}$ at various temperature, $\mathrm{pH}$, time intervals and alginate sodium concentrations. The effect of temperature on alginate lyase activity was determined at temperature ranging from 20 to $40{ }^{\circ} \mathrm{C}$. The $\mathrm{pH}$ effect was determined at $\mathrm{pH}$ ranging from 5 to 9 at an interval of 1-pH unit. The effect of alginate sodium concentrations was determined at the concentrations ranging from 0 to $1.2 \%$ at an interval of $0.2 \%$ unit. The effect of fermentation time was determined at time ranging from 0 to $24 \mathrm{~h}$ at an interval of $4 \mathrm{~h}$. Unless otherwise specified, all fermentations were performed at $30{ }^{\circ} \mathrm{C}$ and $\mathrm{pH}$ 7.0. Alginate lyase activity was measured as described above.

\section{Detection of degradation product of alginate lyase}

Thin layer chromatography (TLC) was applied to analyze alginate oligosaccharides produced by novel alginate lyase-exerting stains. TLC was performed according to the method described by Huang et al. (2013) and the loading volume was $2 \mu \mathrm{l}$. Fermentation samples at different time were collected and spotted on a TLC plate (Merck, Germany) with 1-butanol/formic acid/ water (4:6:1 v:v:v) as a mobile solvent. Then the plate was sprayed with $10 \%(\mathrm{v} / \mathrm{v})$ sulfuric acid in ethanol and heated at $110{ }^{\circ} \mathrm{C}$ for $10 \mathrm{~min}$.

The fermentation broth of LJ-3 with AOs was collected and precipitated by adding ethanol (3 volumes) to remove higher molecular weight components. The solution was centrifuged at 12,000 rpm centrifuging for $15 \mathrm{~min}$, then the supernatant was freeze-drying and then re-dissolved in deionized water. ESI-MS analysis was performed using a LCQ Fleet mass spectrometer (Thermo Fisher Scientific, USA) in negative mode.

\section{Sequences accession and strain deposition}

$16 \mathrm{~S}$ rRNA gene sequences of identified alginate lyaseexcreting strains were submitted and available in the GenBank Database under the Accession Number KX959962-KX959973. The deposition number of LJ-3 was CGMCC 12,155.

\section{Results}

\section{Identification of alginate lyase-excreting bacteria}

Our primary screening identified 196 colonies from the three brown algae [106 from L. japonica (LJ), 53 from $S$. horneri (SH) and 37 from S. siliquatrum (SS)]. Gram's iodine staining showed that 46 colonies had distinct zones of clearance (Fig. 1a). These 46 strains with clearance zone were selected and subjected to 16S rRNA gene amplification. Sequence analysis revealed that many of the 16S rRNA gene sequences were the identical, or only one base-pair difference and these are considered as the same bacterial strain. After removing the duplicates, a total of 12 different strains were identified, including 5 from L. japonica, 4 from S. horneri and 3 from S. siliquatrum. BLAST analysis revealed that bacterial strains belonged to eight genera, namely Paenibacillus (4/12), Bacillus (2/12), Leclercia (1/12), Isoptericola (1/12), Planomicrobium (1/12), Pseudomonas (1/12), Lysinibacillus $(1 / 12)$ and Sphingomonas (1/12) (Table 1, Fig. 1b). Neighbor-joining phylogenetic analysis based on the $16 \mathrm{~S}$ rRNA gene sequences further confirmed the identity of these 12 strains (Fig. 2). Gram staining and microscopic observation also showed that these strains were in accordance with their associated species (Table 1; Additional file 1: Figure S1).

\section{Evaluation of alginate lyase activities}

As shown in Fig. 3a, the oxford cup assay showed that alginate lyase activity varies among the 12 different strains. LJ-3 strain (Bacillus halosaccharovorans) showed the highest alginate lyase activity, with a clearance zone diameter of $2.3 \mathrm{~cm}$ (Table 1). This result was further confirmed by the ultraviolet absorption method, which showed the LJ-3 had the highest enzyme activity, followed by LJ-23 (Paenibacillus taichungensis), LJ-32 (Paenibacillus lautus), SH-56 (Isoptericola halotolerans) and SS-92 (Paenibacillus jamilae) (Fig. 3). The ultraviolet absorption method was applied to verify the accuracy of Gram's iodine method. As shown in Fig. 3b, the variation tendencies of enzyme activity measured by two methods were consistent. 
a

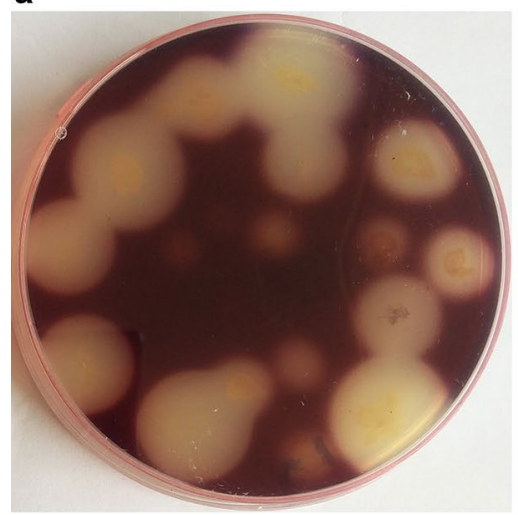

b

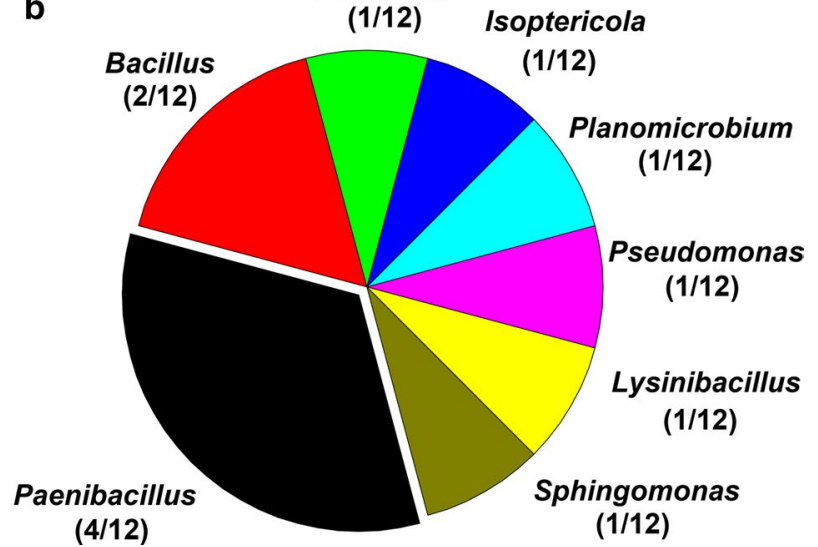

Fig. 1 Isolation and identification of alginate lyase-excreting strains. a Gram's iodine staining, showing the distinct zones of clearance of the alginate lyase-excreting strains (one of the screening plates for result exhibition). b Abundances of the alginate lyase-excreting bacteria strains

Table 1 Identified isolates, each with the closest type strain, the $16 \mathrm{~S}$ rRNA gene similarity and the observed enzyme activities

\begin{tabular}{|c|c|c|c|c|c|}
\hline Strain ID & $\begin{array}{l}\text { Closest bacterial } \\
\text { strain (EZTaxon) }\end{array}$ & Identity (\%) & $\begin{array}{l}\text { Accession } \\
\text { number }\end{array}$ & Gram staining & $\begin{array}{l}\text { Diameter of } \\
\text { clearance zone }(\mathrm{cm})\end{array}$ \\
\hline LJ-3 & Bacillus halosaccharovorans & 98.07 & KX959962 & Positive & $2.3 \pm 0.2$ \\
\hline LJ-16 & Leclercia adecarboxylata & 99.37 & KX959963 & Negative & $0.8 \pm 0.1$ \\
\hline$\llcorner J-22$ & Paenibacillus odorifer & 99.11 & KX959964 & Negative & $1.4 \pm 0.2$ \\
\hline$\llcorner J-23$ & Paenibacillus taichungensis & 99.25 & KX959965 & Negative & $1.7 \pm 0.2$ \\
\hline$\llcorner J-32$ & Paenibacillus lautus & 99.21 & KX959966 & Negative & $1.7 \pm 0.2$ \\
\hline $\mathrm{SH}-45$ & Planomicrobium okeanokoites & 99.24 & KX959967 & positive & $1.2 \pm 0.1$ \\
\hline SH-56 & Isoptericola halotolerans & 98.69 & KX959968 & positive & $1.6 \pm 0.2$ \\
\hline SH-63 & Bacillus oceanisediminis & 99.64 & KX959969 & positive & $1.4 \pm 0.1$ \\
\hline SH-78 & Pseudomonas antarctica & 99.71 & KX959970 & Negative & $1.1 \pm 0.1$ \\
\hline SS-86 & Lysinibacillus macroides & 99.26 & KX959971 & Positive & $0.8 \pm 0.1$ \\
\hline SS-88 & Sphingomonas leidyi & 99.06 & KX959972 & Negative & $1.1 \pm 0.1$ \\
\hline SS-92 & Paenibacillus jamilae & 99.27 & KX959973 & Negative & $1.5 \pm 0.2$ \\
\hline
\end{tabular}

Optimization of growth conditions for production of alginate lyase secreted by LJ-3 strain

The LJ-3 strain had the highest enzyme activity and therefore was chosen to perform further enzymatic at different temperature (Fig. 4a), pH (Fig. 4b), sodium alginate concentration (Fig. 4c) and fermentation time (Fig. 4d). Our results showed that the optimal condition for enzyme production was $30{ }^{\circ} \mathrm{C}, \mathrm{pH} 7.0,0.6 \%$ sodium alginate and $24 \mathrm{~h}$. The relative enzyme activity was changed in accordance with the value of $\mathrm{OD}_{600}$. For example, the value of $\mathrm{OD}_{600}$ showed little change from 30 to $40{ }^{\circ} \mathrm{C}$, so did the enzyme activity, which was maintained at level of above $80 \%$ (Fig. 4a). This result suggested that high microbial biomass produces a high yield of alginate lyase.
Product analysis of alginate lyase-excreting strains

Thin layer chromatography (TLC) was applied to examine the alginate oligosaccharides (AOs) with different degrees of polymerization (DP) produced by different alginate lyase-excreting strains. The alginate lyase-excreting strains including four strains with high enzymatic activity (LJ-3, LJ-23, LJ-32 and SS-92) and three strains with relatively low enzymatic activity (LJ-16, LJ-22, $\mathrm{SH}-45)$ were selected for the tests. As shown in Fig. 5a, AOs were detected in majority of the fermentation broths except LJ-16 and SH-45. The degrees of polymerization of AOs and appearance time of AOs were different. Low molecular weight AOs (DP 2-5) were first detected at $8 \mathrm{~h}$ in fermentation broth of LJ-3 and LJ-32 strains. During 8-16 h, the amount of oligosaccharides gradually 


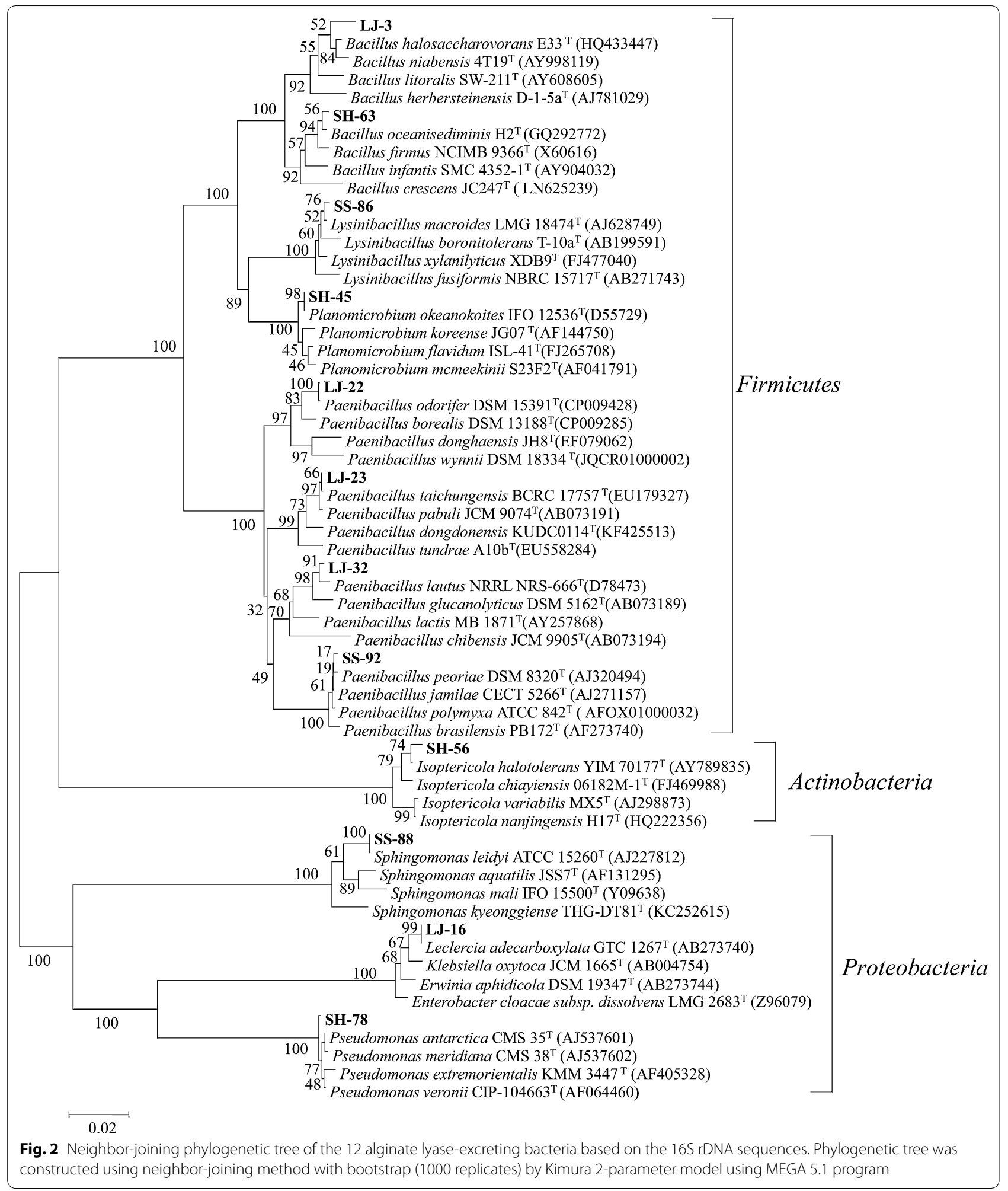

decreased. After $16 \mathrm{~h}$, both DPs and the amount of oligosaccharides significantly decreased. The alginate oligosaccharides produced by LJ-3 strain were further confirmed by ESI-MS analysis. It was showed that the top 3 abundance oligomers were alginate oligosaccharide trimer, dimer and tetramer according to molecular 


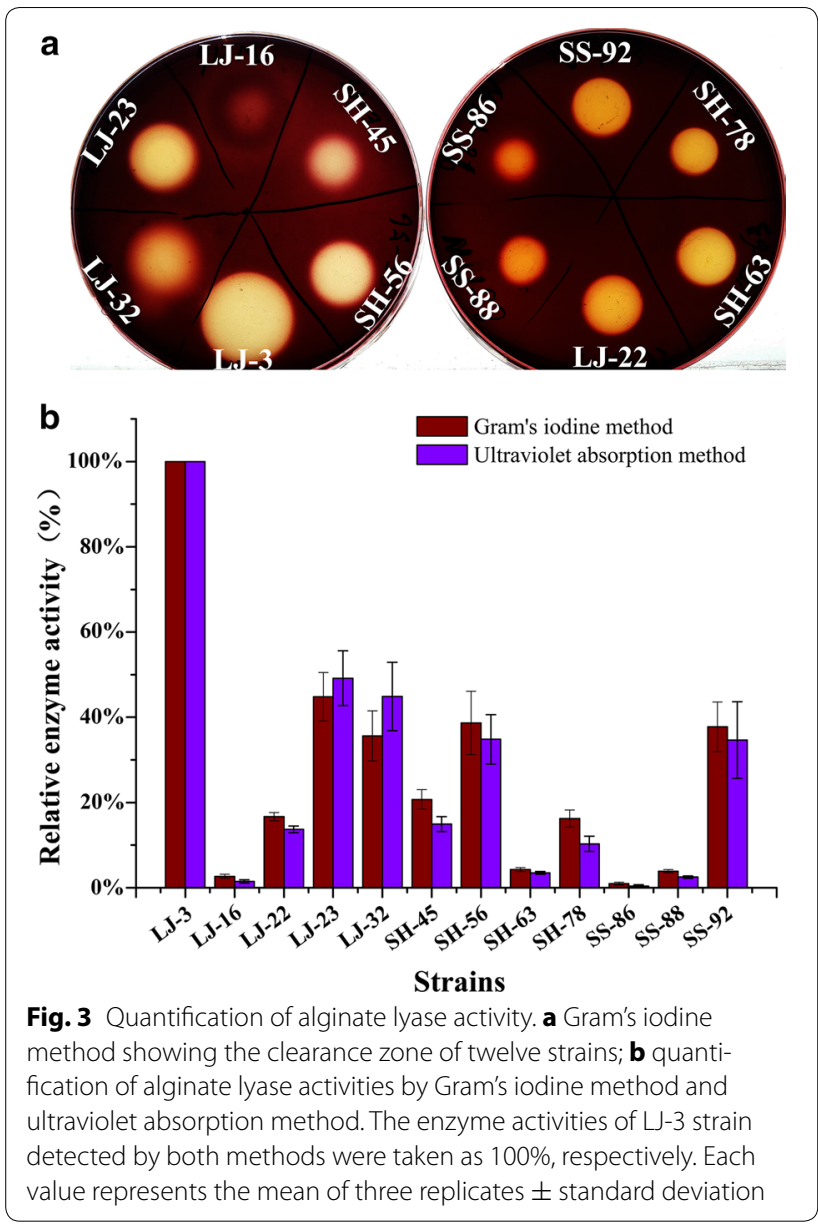

weight determination (Fig. 5b). This result coincided with the TLC detection.

In fermentation broth of LJ-23 and SS-92 strains, AOs were also first detected at $8 \mathrm{~h}$ but the amount and DPs were maximized during $12-16 \mathrm{~h}$. AOs were first detected at $16 \mathrm{~h}$ in fermentation broth of LJ-22 strain and only oligomers of DP2 and DP3 were detected. This result indicated that the alginate lyases of the five stains had different endolytic reaction mode. Thus, these alginate lyases could be useful tools for the preparation of alginate oligosaccharides with different DPs.

No AOs in fermentation broth of LJ-16 and SH- 45 were detected. We inferred that the enzyme activities of LJ-16 and SH- 45 strains were too low to produce enough oligosaccharides for detection by TLC or the consumption of oligosaccharides by strains was too fast to detect at 4-h sampling interval.

\section{Discussion}

Bacteria screening is generally time consuming and labor-intensive. In our study, we applied Gram's iodine method to isolate alginate lyase-excreting microorganism and confirmed that it was practical and convenient. The screening procedure was shown in Additional file 2: Figure S2. In combination with oxford cup method, we modified the Gram's iodine method to achieve quantitative analysis of alginate lyase activity on a single plate. The quantification is validated with ultraviolet absorption method. The Gram's iodine method requires no special equipment, making it suitable for large-scale screening and comparing of alginate lyase-excreting microorganism.

In the past several years, numerous alginate lyases have been isolated from different microorganisms, especially from those associated with brown algae. For example, 21 alginate lyase-excreting strains were isolated from the surface of the Arctic Laminaria and some cold-adapted alginate lyases were identified (Dong et al. 2012). More recently, Martin et al. (2015) isolated and identified 14 alginate lyase-excreting strains associated with the brown alga Ascophyllum nodosum, including one novel strain of Marinomonas. In this study, we identified 12 alginate lyase-excreting strains from the surfaces of three brown algae. Among them, novel alginolytic activity in Paenibacillus, Leclercia and Planomicrobium has not been previously reported. Paenibacillus produces many kinds of extracellular enzymes such as cellulose, proteases, amylase and other polysaccharide-degrading enzymes, which can be used in a wide range of industrial fields (Adlakha et al. 2015; Budi et al. 2000; Das et al. 2016; Dong et al. 2016; Lan Pham et al. 1998; Mathews et al. 2016). However, production of alginate lyase by Paenibacillus has never been reported. In this study, 4 alginate lyaseexcreting strains belonging to Paenibacillus (LJ-22, LJ-23, LJ-32 and SS-92) were isolated from two different algae (L. japonica and S. siliquatrum). As shown in Additional file 3: Table S1, three of them (LJ-23, LJ-32 and SS-92) showed high enzyme activities compared to enzyme 

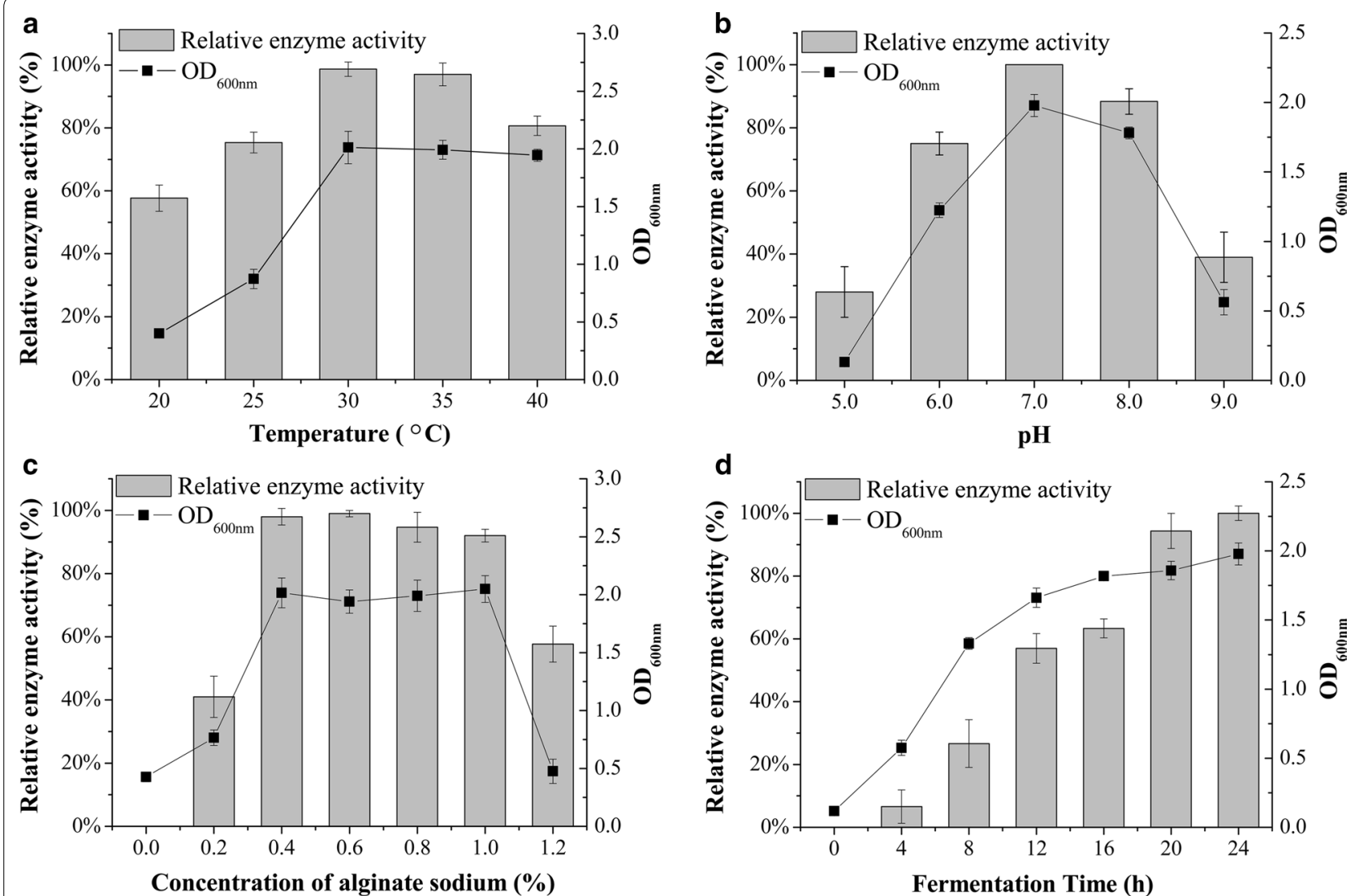

Fig. 4 Optimization of growth conditions for production of alginate lyase secreted by $L J-3$ strain. a Temperature; $\mathbf{b} \mathrm{pH}$; $\mathbf{c}$ sodium alginate concentration and $\mathbf{d}$ fermentation time. Each value represents the mean of three replicates \pm standard deviation

activities published previously (Li et al. 2015; Zhu et al. 2015a, b; 2016a). Our results indicated that Paenibacillus is a potential source for novel alginate lyase.

Although alginate lyases from the genus Bacillus were found in a few reports (Nakagawa et al. 1998), they may play an important role in aquaculture and agriculture. Recently, an alginate-degrading Bacillus strain was applied to improve the seaweed (L. japonica) based diet for sea cucumber (Apostichopus japonicas) (Wang et al. 2015). An alginate lyase-excreting strain (LJ-3) belonging to Bacillus genus was isolated in our study and it has potential to be used in industry due to its high enzyme activity. It could also be used as plant stimulant in agriculture. We showed that alginate oligosaccharides 


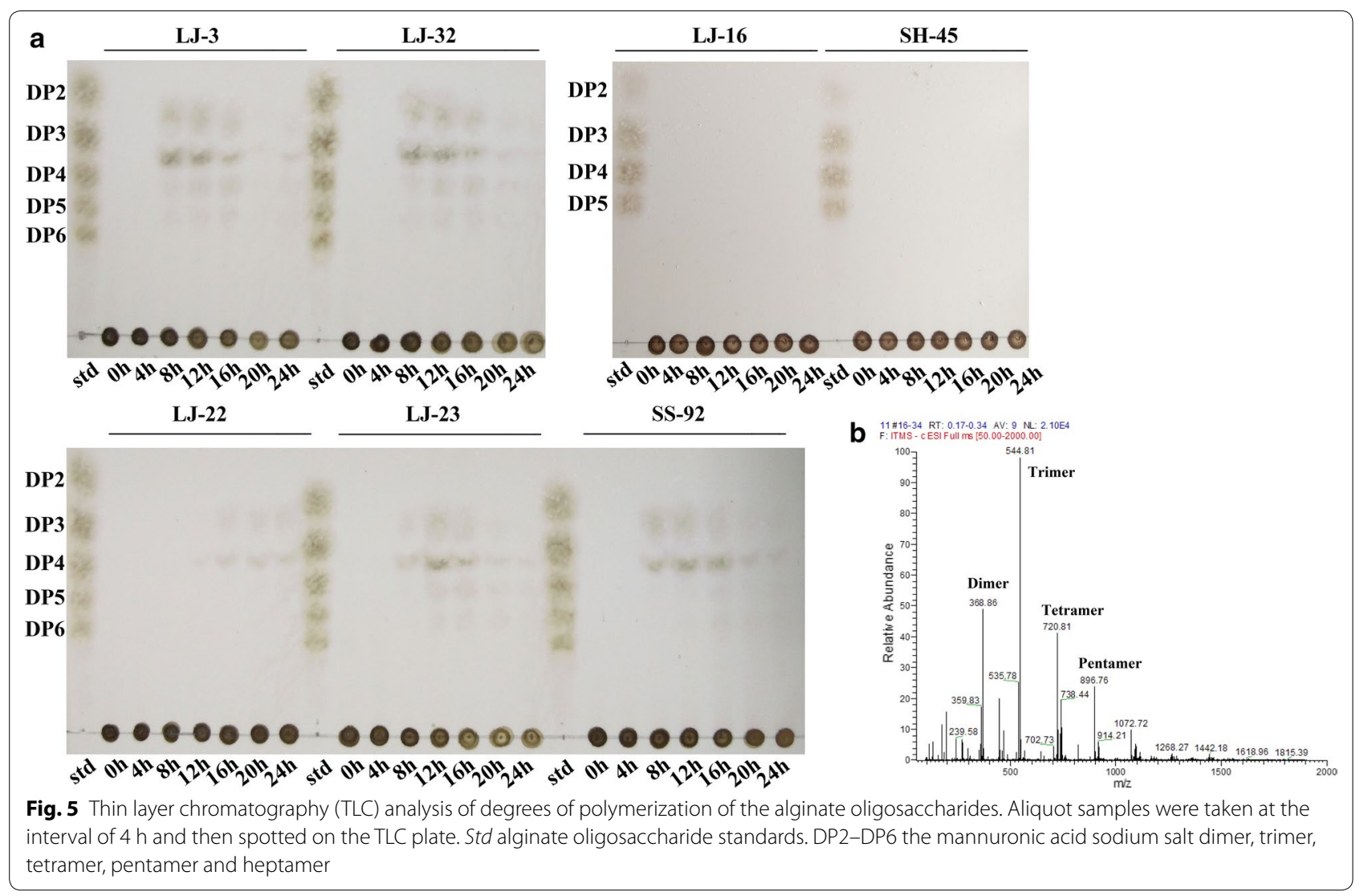

produced by LJ-3 strain could improve growth and quality of plants (unpublished data), especially promote early fruit coloring (Additional file 4: Figure S3).

\section{Additional files}

Additional file 1: Figure S1. Gram staining of the 12 alginate lyaseexcreting bacterial strains.

Additional file 2: Figure S2. Flow chart of screening procedure.

Additional file 3: Table S1. Comparison of alginate lyase activities in different strains.

Additional file 4: Figure S3. The fruit coloring promotion effect of alginate oligosaccharide on different plants.

\section{Abbreviations}

OD: optical density; SD: standard deviation; AOs: alginate oligosaccharides; DP: degrees of polymerization; L: Laminaria japonica; SH: Sargassum horneri; SS: Sargassum siliquatrum; ALG: alginate.

\section{Authors' contributions}

WMP and CL designed the work, performed the research study and drafted the manuscript. ZZJ was involved in critically revision the manuscript. WXJ guided and participated in collection of algae samples. QS and YPS designed and supervised the research study. All authors read and approved the final manuscript.

\section{Author details}

${ }^{1}$ School of Municipal and Environmental Engineering, Harbin Institute of Technology, Harbin 150090, China. ${ }^{2}$ Yantai Institute of Costal Zone Research
Chinese Academy of Sciences, 17 Chunhui Road, Yantai 264003, Shandong province, China. ${ }^{3}$ Department of Zoology and Physiology, University of Wyoming, Laramie, WY, USA. ${ }^{4}$ Worldfull Agricultural Science and Technology Co. Ltd, Yantai 264000, China. ${ }^{5}$ School of Marine Science and Technology, Harbin Institute of Technology at Weihai, West Culture Road 2, Weihai 264209, Shandong Province, China.

\section{Acknowledgements}

Not applicable.

\section{Competing interests}

The authors declare that they have no competing interests.

\section{Availability of data and materials}

The datasets supporting the conclusions of this article are included in the main manuscript file and Additional files 1, 2, 3, 4 .

\section{Funding}

This work was supported by the National Key Technology R\&D Program of China (2013BAB01B0), the Young Scientists Fund of National Natural Science Foundation of China (41401285), the Public Science and Technology Research Funds Projects of Ocean (201505022), the Chinese Academy of Sciences Strategic Pilot Project (XDA1 102040300) and Shandong Science and Technology Development Project (2010GSF10208).

\section{Publisher's Note}

Springer Nature remains neutral with regard to jurisdictional claims in published maps and institutional affiliations.

Received: 13 January 2017 Accepted: 2 March 2017

Published online: 04 April 2017 


\section{References}

Adlakha N, Pfau T, Ebenhoh O, Yazdani SS (2015) Insight into metabolic pathways of the potential biofuel producer, Paenibacillus polymyxa ICGEB2008. Biotechnol Biofuels 8:159. doi:10.1186/s13068-015-0338-4

Baron AJ, Wong TY, Hicks SJ, Gacesa P, Willcock D, Mcpherson MJ (1994) Alginate lyase from Klebsiella pneumoniae, subsp. aerogenes: gene cloning, sequence analysis and high-level production in Escherichia coli. Gene 143(1):61-66

Beveridge TJ (2001) Use of the Gram stain in microbiology. Biotech Histochem 76(3):111-118

Budi SW, van Tuinen D, Arnould C, Dumas-Gaudot E, Gianinazzi-Pearson V, Gianinazzi S (2000) Hydrolytic enzyme activity of Paenibacillus sp. strain B2 and effects of the antagonistic bacterium on cell integrity of two soil-borne pathogenic fungi. Appl Soil Ecol 15(2):191-199. doi:10.1016/ S0929-1393(00)00095-0

Das SN, Wagenknecht M, Nareddy PK, Bhuvanachandra B, Niddana R, Balamurugan R, Swamy MJ, Moerschbacher BM, Podile AR (2016) Amino groups of chitosan are crucial for binding to a family 32 carbohydrate binding module of a chitosanase from Paenibacillus elgii. J Biol Chem. doi:10.1074/ jbc.M116.721332

Dong S, Yang J, Zhang XY, Shi M, Song XY, Chen XL, Zhang YZ (2012) Cultivable alginate lyase-excreting bacteria associated with the Arctic brown alga Laminaria. Mar Drugs 10(11):2481-2491. doi:10.3390/md10112481

Dong M, Yang Y, Tang X, Shen J, Xu B, Li J, Wu Q, Zhou J, Ding J, Han N, Mu Y, Huang Z (2016) NaCl-, protease-tolerant and cold-active endoglucanase from Paenibacillus sp. YD236 isolated from the feces of Bos frontalis. Springerplus 5(1):746. doi:10.1186/s40064-016-2360-9

Dou W, Wei D, Li H, Li H, Rahman MM, Shi J, Xu Z, Ma Y (2013) Purification and characterisation of a bifunctional alginate lyase from novel Isoptericola halotolerans CGMCC 5336. Carbohydr Polym 98(2):1476-1482. doi:10.1016/j.carbpol.2013.07.050

Falkeborg M, Cheong LZ, Gianfico C, Sztukiel KM, Kristensen K, Glasius M, Xu X, Guo Z (2014) Alginate oligosaccharides: enzymatic preparation and antioxidant property evaluation. Food Chem 164:185-194. doi:10.1016/j. foodchem.2014.05.053

Gacesa P (1988) Alginates. Carbohyd Polym 8(3):161-182. doi:10.1016/0144-8617(88)90001-X

Gacesa P, Wusteman FS (1990) Plate assay for simultaneous detection of alginate lyases and determination of substrate specificity. Appl Environ Microbiol 56(7):2265-2267

Huang L, Zhou J, Li X, Peng Q, Lu H, Du Y (2013) Characterization of a new alginate lyase from newly isolated Flavobacterium sp. S20. J Ind Microbiol Biotechnol 40(1):113-122. doi:10.1007/s10295-012-1210-1

Ji MH (1997) Seaweed chemistry. Science Press, Beijing

Kawamoto H, Horibe A, Miki Y, Kimura T, Tanaka K, Nakagawa T, Kawamukai M, Matsuda $H$ (2006) Cloning and sequencing analysis of alginate lyase genes from the marine bacterium Vibrio sp. $\mathrm{O}_{2}$. Mar Biotechnol (NY) 8(5):481-490. doi:10.1007/s10126-005-6157-z

Khan S, Tondervik A, Sletta H, Klinkenberg G, Emanuel C, Onsoyen E, Myrvold R, Howe RA, Walsh TR, Hill KE, Thomas DW (2012) Overcoming drug resistance with alginate oligosaccharides able to potentiate the action of selected antibiotics. Antimicrob Agents Chemother 56(10):5134-5141. doi:10.1128/AAC.00525-12

Kumar S, Nei M, Dudley J, Tamura K (2008) MEGA: a biologist-centric software for evolutionary analysis of DNA and protein sequences. Brief Bioinform 9(4):299-306. doi:10.1093/bib/bbn017

Lan Pham P, Taillandier P. Delmas M. Strehaiano P (1998) Production of xylanases by Bacillus polymyxa using lignocellulosic wastes. Ind Crop Prod 7(2-3):195-203. doi:10.1016/S0926-6690(97)00048-4

Li S, Yang X, Zhang L, Yu W, Han F (2015) Cloning, expression, and characterization of a cold-adapted and surfactant-stable alginate lyase from marine bacterium Agarivorans sp. L11. J Microbiol Biotechnol 25(5):681-686

Martin M, Barbeyron T, Martin R, Portetelle D, Michel G, Vandenbol M (2015) The cultivable surface microbiota of the brown alga Ascophyllum nodosum is enriched in macroalgal-polysaccharide-degrading bacteria. Front Microbiol 6:1487. doi:10.3389/fmicb.2015.01487

Mathews SL, Smithson CE, Grunden AM (2016) Purification and characterization of a recombinant laccase-like multi-copper oxidase from Paenibacillus glucanolyticus SLM1. J Appl Microbiol. doi:10.1111/jam.13241

Matsubara Y, Kawada R, Iwasaki K, Kimura Y, Oda T, Muramatsu T (2000) Cloning and sequence analysis of a gene (aly PG) encoding
poly(alpha-L-guluronate)lyase from Corynebacterium sp. strain ALY-1. J Biosci Bioeng 89(2):199-202

Nakagawa A, Ozaki T, Chubachi K, Hosoyama T, Okubo T, lyobe S, Suzuki T (1998) An effective method for isolating alginate lyase-producing Bacillus sp. ATB-1015 strain and purification and characterization of the lyase. J Appl Microbiol 84(3):328-335. doi:10.1046/j.1365-2672.1998.00319.x

Park HJ, Ahn JM, Park RM, Lee SH, Sekhon SS, Kim SY, Wee JH, Kim YH, Min $J$ (2016) Effects of alginate oligosaccharide mixture on the bioavailability of lysozyme as an antimicrobial agent. J Nanosci Nanotechnol 16(2):1445-1449

Preiss J, Ashwell G (1962) Alginic acid metabolism in bacteria. I. Enzymatic formation of unsaturated oligosaccharides and 4-deoxy-L-erythro-5-hexoseulose uronic acid. J Biol Chem 237(2):309-316

Saigusa M, Nishizawa M, Shimizu Y, Saeki H (2015) In vitro and in vivo anti-inflammatory activity of digested peptides derived from salmon myofibrillar protein conjugated with a small quantity of alginate oligosaccharide. Biosci Biotechnol Biochem 79(9):1518-1527. doi:10.1080/091684 51.2015 .1031075

Sawant SS, Salunke BK, Kim BS (2015) A rapid, sensitive, simple plate assay for detection of microbial alginate lyase activity. Enzyme Microb Technol 77:8-13. doi:10.1016/j.enzmictec.2015.05.003

Takeshita S, Oda T, Muramatsu T (1991) An improved plate method, in the presence of calcium chloride or sulfuric acid, for simultaneous detection of alginate lyases. Agric Biol Chem 55(10):2637-2638

Wan LS, Heng PW, Chan LW (1992) Drug encapsulation in alginate microspheres by emulsification. J Microencapsul 9(3):309-316. doi:10.3109/02652049209021245

Wang X, Wang L, Che J, Li Z, Zhang J, Li X, Hu W, Xu Y (2015) Improving the quality of Laminaria japonica-based diet for Apostichopus japonicus through degradation of its algin content with Bacillus amyloliquefaciens WB1. Appl Microbiol Biotechnol 99(14):5843-5853. doi:10.1007/ s00253-015-6583-4

Wong TY, Preston LA, Schiller NL (2000) Alginate lyase: review of major sources and enzyme characteristics, structure-function analysis, biological roles, and applications. Annu Rev Microbiol 54:289-340. doi:10.1146/annurev. micro.54.1.289

Xu X, Bi D, Wan M (2015) Characterization and immunological evaluation of low-molecular-weight alginate derivatives. Curr Top Med Chem 16(8):874-887. doi:10.2174/1568026615666150827101239

Yang JH, Bang MA, Jang CH, Jo GH, Jung SK, Ki SH (2015) Alginate oligosaccharide enhances $L D L$ uptake via regulation of LDLR and PCSK9 expression. J Nutr Biochem 26(11):1393-1400. doi:10.1016/j.jnutbio.2015.07.009

Zhou R, Shi XY, Bi DC, Fang WS, Wei GB, Xu X (2015) Alginate-derived oligosaccharide inhibits neuroinflammation and promotes microglial phagocytosis of beta-amyloid. Mar Drugs 13(9):5828-5846. doi:10.3390/ md13095828

Zhu BW, Yin H (2015) Alginate lyase: review of major sources and classification, properties, structure-function analysis and applications. Bioengineered 6(3):125-131 doi:10.1080/21655979.2015.1030543

Zhu BW, Huang LS, Tan HD, Qin YQ, Du YG, Yin H (2015a) Characterization of a new endo-type polyM-specific alginate lyase from Pseudomonas sp. Biotechnol Lett 37(2):409-415. doi:10.1007/s10529-014-1685-0

Zhu BW, Tan HD, Qin YQ, Xu QS, Du YG, Yin H (2015b) Characterization of a new endo-type alginate lyase from Vibrio sp. W13. Int J Biol Macromol 75:330-337. doi:10.1016/j.ijbiomac.2015.01.053

Zhu BW, Chen MJ, Yin H, Du YG, Ning LM (2016a) Enzymatic hydrolysis of alginate to produce oligosaccharides by a new purified endo-type alginate lyase. Mar Drugs 14(6):108. doi:10.3390/md14060108

Zhu Y, Wu L, Chen Y, Ni H, Xiao A, Cai H (2016b) Characterization of an extracellular biofunctional alginate lyase from marine Microbulbifer sp. ALW1 and antioxidant activity of enzymatic hydrolysates. Microbiol Res 182:49-58. doi:10.1016/j.micres.2015.09.004 